\title{
RECURRENT ABDOMINAL PAIN
}

\section{When an epileptic seizure should be suspected?}

\author{
Renata C. Franzon 1, Camila F. Lopes², Kátia M.R. Schmutzler³, \\ Maria Isabel R. Morais', Marilisa M. Guerreiro ${ }^{4}$
}

\begin{abstract}
Recurrent episodes of abdominal pain are common in childhood. Among the diagnostic possibilities are migraine and abdominal epilepsy (AE). AE is an infrequent syndrome with paroxystic episodes of abdominal pain, awareness disturbance, EEG abnormalities and positive results with the introduction of antiepileptic drugs. We present one 6 year-old girl who had short episodes of abdominal pain since the age of 4 . The pain was followed by cry, fear and occasionally secondary generalization. MRI showed tumor in the left temporal region. As a differential diagnosis, we report a 10 year-old boy who had long episodes of abdominal pain accompanied by blurring of vision, vertigo, gait ataxia, dysarthria, acroparesthesias and vomiting. He received the diagnosis of basilar migraine. In our opinion, AE is part of a large group (partial epilepsies) and does not require a special classification. Pediatric neurologists must be aware of these two entities that may cause abdominal pain.
\end{abstract}

KEY WORDS: partial seizures, temporal lobe tumor, basilar migraine, abdominal pain, symptomatic epilepsy.

\section{Dor abdominal recorrente: quando suspeitar de crise epiléptica?}

RESUMO - Episódios recorrentes de dor abdominal são freqüentes na infância e entre as causas neurológicas há migrânea e epilepsia abdominal (EA). EA é uma síndrome que consiste de episódios paroxísticos de dor abdominal associada à alteração de consciência, anormalidades eletrencefalográficas e boa resposta à terapia anticonvulsivante. Apresentamos uma menina de 6 anos que tinha desde os 4 anos episódios de curta duração de dor abdominal, seguidos por choro, medo e ocasional generalização secundária. A RM mostrou a presença de um tumor em região temporal esquerda. Como diagnóstico diferencial, apresentamos um menino de 10 anos que há 12 meses referia episódios de dor abdominal de longa duração acompanhados por turvação visual, vertigem, marcha atáxica, disartria, acroparestesia e vômito, recebendo posteriormente o diagnóstico de migrânia basilar. Em nossa opinião, EA faz parte de um grande grupo (epilepsias parciais) e não requer uma classificação especial. O neuropediatra deve estar alerta para essas duas entidades que podem cursar com dor abdominal.

PALAVRAS-CHAVE: crises parciais, tumor do lobo temporal, migrânea basilar, dor abdominal e epilepsia sintomática.

Recurrent episodes of abdominal pain are common in childhood. In a minority of patients in which an abdominal pathology is excluded a neurologic cause should be considered. Among the diagnostic possibilities are migraine and abdominal epilepsy $(A E) . A E$ is an infrequent syndrome with paroxystic episodes of abdominal or visceral pain, with awareness disturbance, EEG abnormalities and good results with the introduction of antiepileptic drugs (AED) $)^{1-4}$.

Migraine is more frequent than AE and may occur in a classical form or as a distinct subentity, such as basilar migraine ${ }^{3}$. The latter consists of sudden, transitory episodes of visual blurring, vertigo, gait ataxia, dysarthria, acroparesthesias and a pulsatile occipital headache with vomiting ${ }^{5}$.

Our objective is to present two patients with recurrent abdominal pain and different diagnosis.

\section{CASOS}

We report two children with recurrent abdominal pain having had unremarkable pediatric evaluation. Both pa-

\footnotetext{
Departamento de Neurologia, Faculdade de Ciências Medicas, Universidade Estadual de Campinas (FCM/UNICAMP), Campinas SP, Brasil: ${ }^{1}$ Pós-graduanda; ${ }^{2}$ Residente; ${ }^{3}$ Médica Assistente Doutora; ${ }^{4}$ Professora Doutora.
}

Received 2 January 2002, received in final form 20 March 2002. Accepted 26 March 2002.

Dra. Marilisa M. Guerreiro. Departamento de Neurologia, FCM / UNICAMP - Caixa Postal 6111 - 13083-970 Campinas São Paulo SP Brasil.E-mail:mmg@fcm.unicamp.br 
tients had detailed clinical histories, neurologic examinations and complementary exams (EEG, CT, MRI). The final diagnosis was different in the two patients. The follow-up is 18 months for both children.

Patient 1. A six year-old girl has had recurrent abdominal pain since 4 year- old, which she sometimes described as "my belly is dreaming". The duration of the episodes ranged from seconds to few minutes and crying and a "facies" of fear followed the pain. The frequency was initially once a day and progressively increased to six a day. Some of them were followed by awareness disturbance and occasionally a tonic-clonic seizure. After a nega- tive abdominal investigation (including stool exams for ova and parasites, abdominal ultra-sound and routine blood exams, such as, liver, pancreas and renal function tests), she was referred to a child neurologist who found behavior alterations (hyperactivity and impulsivity). The remaining of the neurologic examination was otherwise normal. After that, she had refractory seizures with secondary generalization. She underwent an EEG exam and cranium CT scan, which showed a hypodense area in left temporal area. She was then referred to a tertiary care center in order to undergo further exams. MRI revealed a tumor in the left temporal lobe (Fig 1). Interictal EEG showed spikes and slow waves over left temporal lobe. Mus-

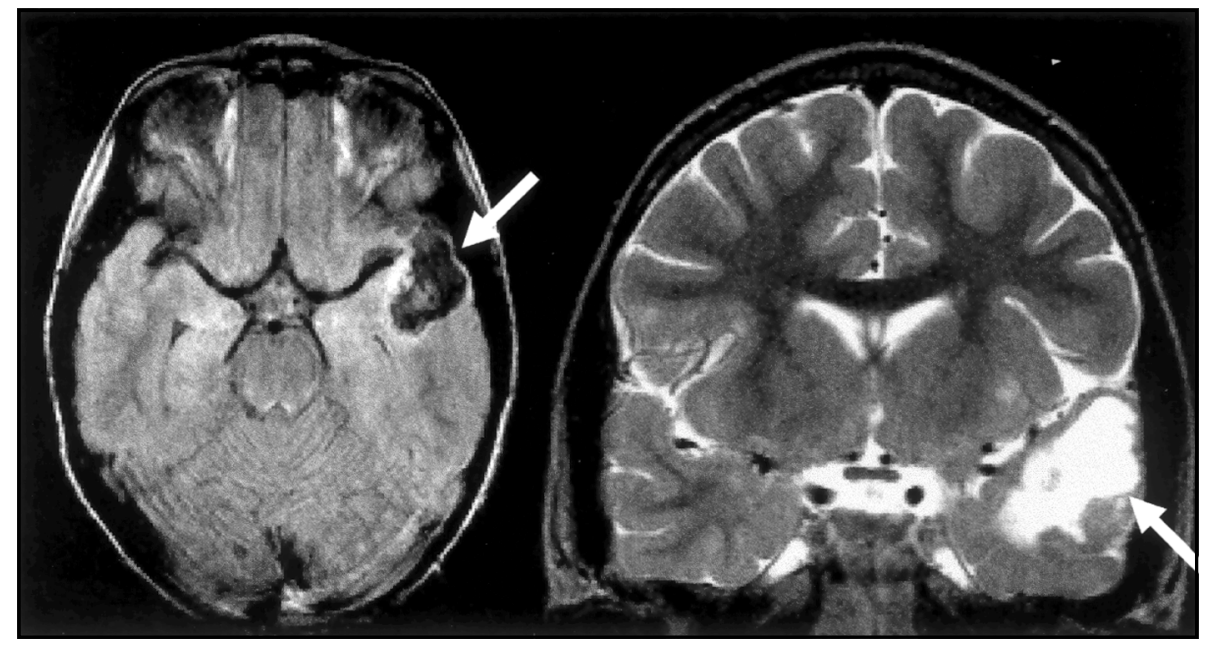

Fig 1. Patient 1. MRI. The figures show a cystic lesion with solid mural nodule on left temporal lobe.

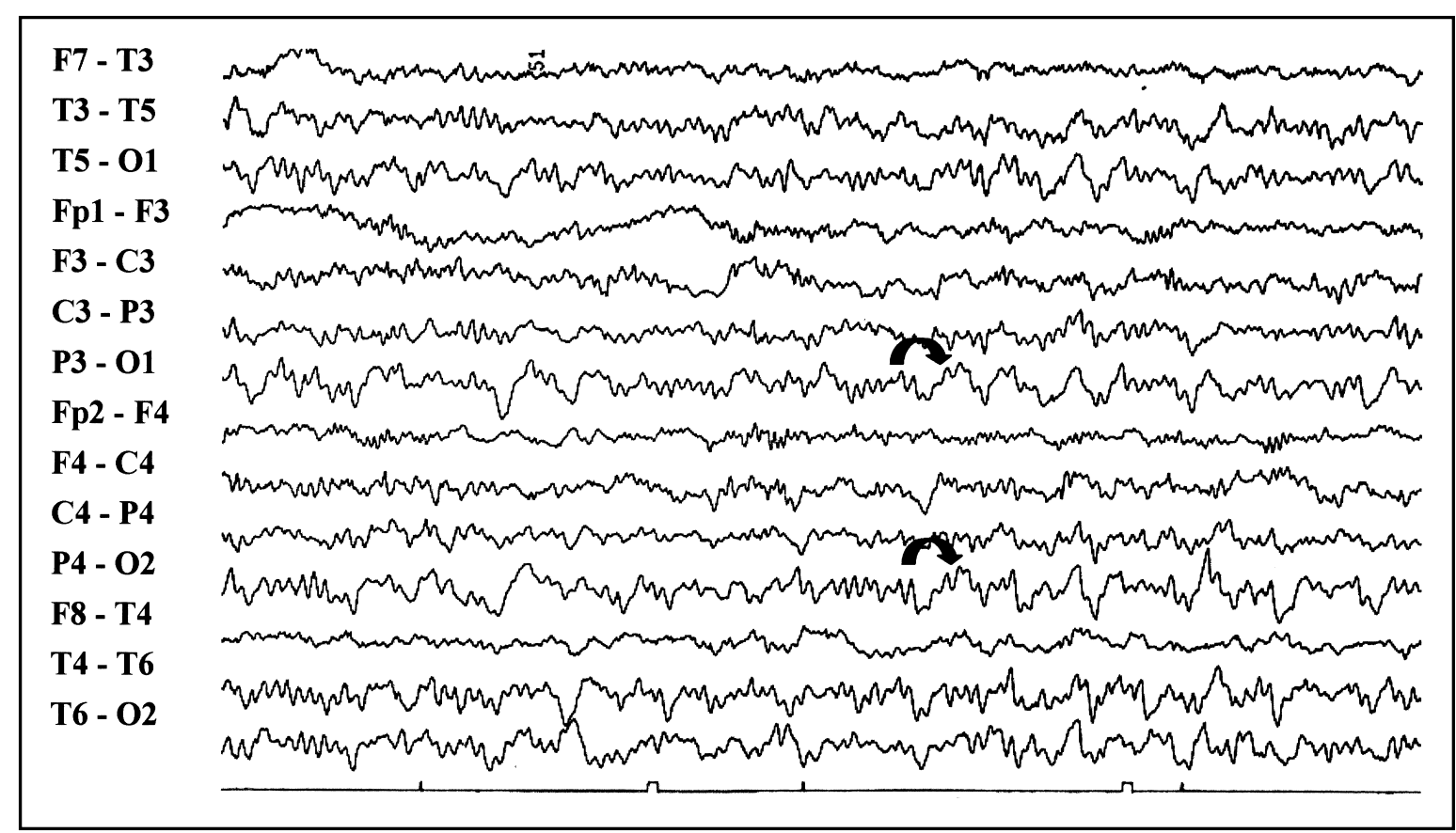

Fig 2. Patient 2. EEG. The figure shows intermittent slow waves (delta range) over occipital regions bilaterally, during an acute episode of basilar migraine. 
cular artifacts contaminated ictal EEG. She had no other seizures after surgical resection. Histopathological exam showed an oligoastrocytoma grade II.

Patient 2. A ten year-old boy was having recurrent episodes of abdominal pain for the past 12 months. The duration of the episodes varied and ranged from hours to days. Blurring of vision, vertigo, ataxic gait, dysarthria, acroparesthesias, and vomiting accompanied them. He underwent an exhaustive abdominal investigation (including complete blood cell count, stool examinations for ova and parasites, abdominal ultra-sound and high digestive endoscopy). He did not improve after carbamazepine was introduced. He underwent an EEG examination during a typical episode of abdominal pain, which revealed lentification in the occipital region (Fig 2). A diagnosis of basilar migraine was proposed. He also underwent a MRI, which was normal. He did very well with specific treatment for migraine (Flunarizine).

\section{DISCUSSION}

These two cases show the importance and the difficulty of arriving at a correct diagnosis of the neurological causes of recurrent abdominal pain in childhood.

Patient 1 had the diagnosis of abdominal epilepsy. Two decades ago there were attempts to elaborate criteria for the definition of this entity, which are ${ }^{6,7}$ : paroxystic abdominal pain; exclusion of visceral abdominal pathology; alteration of mental status during at least some episodes; clearly abnormal EEG; and, positive response to AED. Our patient fulfilled all those criteria, however, the presence of paroxysms of abdominal pain (followed or not by secondary generalization) made us believe that she had partial autonomic seizures.

The pathophysiology of abdominal epilepsy remains unknown. Some possible etiologies have been considered, such as prematurity, febrile seizures, and neuroendocrine dysfunction, but they are not convincing. There is a report of a case of abdominal epilepsy due to a cerebral tumor (astrocitoma) in the temporal area ${ }^{8}$. More recently, another case report showed cortical malformation, bilateral perisylvian polymicrogyria, at MRI associated with abdominal epilepsy ${ }^{9}$. When the abdominal pain presents as a short paroxysmal episode followed by either awareness disturbance or automatisms, an epileptic seizure is easily considered and, in those cases, temporal lobe is the most probable origin of the seizure $^{10}$. Nevertheless, abdominal pain in childhood is not an easy symptom to characterize, particularly in young children, and other diagnosis should be considered.
Patient 2 had the diagnosis of basilar migraine. This condition may course with recurrent abdominal pain, which is usually gradual in the beginning, a positive familiar history of migraine, and a normal EEG or one revealing unspecific abnormalities ${ }^{6}$. Being migraine a frequent entity also in the pediatric population, this diagnostic hypothesis should enter the differential diagnosis of abdominal epilepsy.

Both abdominal epilepsy and basilar migraine can present with vomiting. In this case, Panayiotopoulos syndrome has to be considered. Ictal vomiting, deviation of the eyes, and occipital spikes characterize this syndrome. Peak age at onset is 5 years ${ }^{11}$.

Another point to be considered is the EEG. Patients with abdominal epilepsy usually have specific EEG abnormalities, particularly of a temporal lobe seizure disorder ${ }^{7}$, while patients with migraine have normal EEGs or present unspecific abnormalities, as was the case of our patient ${ }^{5}$.

In our opinion, abdominal epilepsy is part of a larger group (partial epilepsies) and does not require a special classification because the abdominal pain is usually associated with other ictal manifestations compatible with the diagnosis of partial seizures ${ }^{3}$. However, it is not uncommon for pediatric neurologists to receive patients referred with this complaint. Therefore, one must be aware of the differential diagnosis of this condition, particularly considering migraine as a possibility because it is much more frequent than epilepsy.

\section{REFERENCES}

1. Bain HW. Abdominal pain in children. Prim Care 1975;2:127-133.

2. Douglas EF, White PT. Abdominal epilepsy: a reappraisal. J Pediatr 1971;78:59-67.

3. Lanzi G, Balottiu U, Ottolini A, Rosano Burgio F, Fazzi E, Arisi D. Cyclic vomiting and recurrent abdominal pain as migraine or epileptic equivalents. Cephalalgia 1983;3:115-118.

4. Zarling EJ. Abdominal epilepsy: an unusual cause of recurrent abdominal pain. Am J Gastroenterol 1984;79:687-688.

5. Niedermeyer E. The EEG in patients with migraine and other forms of headache. In Niedermeyer E, Lopes da Silva F (eds). Electroencephalography: basic principles, clinical applications, and related fields. Philadelphia: Lippincott Williams \& Wilkins, 1999:595-602.

6. Singhi PD, Kaur S. Abdominal epilepsy misdiagnosed as psychogenic pain. Postgrad Med J 1988;64:281-282.

7. Peppercorn MA, Herzog AG. The spectrum of abdominal epilepsy in adults. Am J Gastroenterol 1989;84:1294-1296.

8. Mitchell WG, Greenwood RS, Messenheimer JA. Abdominal epilepsy: cyclic vomiting as the major sympton of simple partial seizures. Arch Neurol 1983;40:251-252.

9. Garcia-Herrero D, Fernandez-Torre JL, Barrasa J, Calleja J, Pascual J. Abdominal epilepsy in an adolescent with bilateral perisylvian polymicrogyria. Epilepsia 1998;39:1370-1374.

10. Henkel A, Noachtar S, Pfander M, Luders HO. The localizing value of the abdominal aura and its evolution: a study in focal epilepsies. Neurology 2002;58:271-276.

11. Caraballo R, Cersosimo R, Medina C, Fejerman N. Panayiotopoulostype benign childhood occipital epilepsy: a prospective study. Neurology 2000;55:1096-1100. 